\title{
Penerapan Aplikasi Google Classroom Dalam Matakuliah Matematika Diskrit Pada Masa Pandemi Covid-19
}

\author{
Eliska Juliangkary ${ }^{1}$, dan Pujilestari ${ }^{2}$ \\ ${ }^{1 \& 2}$ Dosen Prodi Pendidikan Matematika FSTT UNDIKMA Mataram \\ E-mail: eliska01juliangkary@gmail.com, Pujilestari966@gmail.com
}

\begin{abstract}
Abstrak
Pada penelitian ini bertujuan mendeskripsikan belajar mahasiswa menggunakan Aplikasi Google Classroom dalam matakuliah Matematika Diskrit pada masa pandemic covid-19. Penelitian ini dilaksanakan mulai semester ganjil tahun akademik 2020/2021 pada Mahasiswa semester V matakuliah Matematika Diskrit sebanyak 34 orang, Program Studi Pendidikan Matematika. FSTT UNDIKMA Mataram. Instrumen yang digunakan dalam penelitian ini adalah berupa angket/kuisioner dengan menggunakan google form. Wawancara dilakukan pada saat akhir kegiatan belajar mengajar secara daring. Analisis data dilakukan dengan menggunakan excel untuk menghitung jumlah persentase serta nilai ratarata. Indikator angket diberikan pada mahasiswa terdiri dari ; 1) Respon siswa mudah dalam mengakses Aplikasi Google Classroom, 2) keefektifan dalam pembelajaran Matematika Diskrit dalam menggunakan Aplikasi Google Classroom, 3) pemahaman terhadap materi dalam pembelajaran dengan menggunakan Aplikasi Google Classroom, (4) mudah pemahaman materi Matematika Diskrit jika menggunakan aplikasi Aplikasi Google Classroom selama masa Pandemi Covid 19. (5) motivasi mahasiswa dalam melakukan belajar online karena menggunakan Aplikasi Google Classroom,(6) kualiatas interaksi guru dan siswa dalam Pembelajaran menggunakan Aplikasi Google Classroom. Berdasarkan indikator penerapan Aplikasi Google Classroom menunjukan rata-rata mahasiswa menjawab setuju sebesar $75.5 \%$ dan tidak setuju sebesar $25.5 \%$. Hasil tersebut menunjukan bahwa penerapan Google Classroom mendapatkan tanggapan yang baik dari mahasiswa, sehingga dapat digunakan untuk pembelajaran pada matakuliah Matematika Diskrit.
\end{abstract}

Keywords: Aplikasi Google Classroom, Matematika Diskrit, Covid-19

\section{PENDAHULUAN}

Di akhir tahun 2019 dunia digemparkan dengan adanya virus baru yang berasal dari Wuhan, Tiongkok. Virus ini telah melanda 215 negara di dunia. Virus tersebut dikenal dengan istilah COVID-19 atau yang disebut dengan Coronavirus Diseases-19 (Astini, 2020). Virus ini menyerang sistem pernafasan pada manusia dengan gejala gangguan pernafasan akut, demam, batuk dan sesak nafas. Pada tanggal 30 Januari WHO (World Health Organization) telah menetapkan status darurat kesehatan masyarakat yang disebabkan oleh virus ini. Virus ini sangat berdampak dalam berbagai bidang kehidupan, tanpa terkecuali dalam bidang pendidikan. (Gusty, S, 2020)

Bertepatan pada tanggal 2 mei 2020, di peringatan Hardiknas Nadiem (Mendikbud) mengatakan ada pelajaran penyakit covid-19 yang membuat bisa belajar tentang proses belajar diluar kelas, tapi dimana saja, kapan saja, pada masa ini adalah pertama kalinya semua pendidik Indonesia menerapkan sistem pendidikan online selama wabah covid-19 (Trisnawati, 2021)
Tidak terkecuali matakuliah Matematika Diskrit ditempuh oleh Mahasiswa pada masa pandemi covid-19 seperti sekarang ini lebih mudah dilakukan dengan menggunakan metode belajar e-learning. Bertujuan untuk menghindari resiko penyebaran virus covid-19. Salah satu media yang digunakan adalah Google Classroom yang merupakan platform gratis berbasis web yang dibuat untuk mempermudah kegiatan pembelajaran pendidik dan murid. (Juliangkary, 2021)

$$
\text { Aplikasi Google Classroom }
$$

memungkinkan para guru untuk mengatur dan menilai progres murid-muridnya sambil tetap terhubung dari mana pun juga. Para murid bisa menerima dan mengumpulkan tugas langsung di Aplikasi Google Classroom, begitu juga para guru. Layanan ini dapat sangat mengurangi penggunaan kertas dan mempermudah proses pembelajaran, apalagi jika dilakukan secara jarak jauh. Keunggulan Aplikasi Google Classroom yaitu: a) Guru bisa melakukan beberapa tugas dari satu tempat, b) Komunikasi dan kerja sama lancar, dan c) Dokumen tersimpan dengan rapi dan aman. (Aliya, 2021) 
Google classroom dirancang untuk mempermudah interaksi guru dan siswa dalam dunia maya. Aplikasi ini memberikan kesempatan kepada guru untuk mengeksplorasi gagasan keilmuan yang dimilikinya kepada siswanya. Guru memiliki keleluasaan waktu untuk membagikan materi pelajaran dan memberikan tugas mandiri kepada siswa. Guru juga dapat membuka ruang diskusi bagi para

siswa secara online. Melalui aplikasi Google Classroom diasumsikan bahwa tujuan pembelajaran akan lebih mudah direalisasikan dan sarat kebermaknaan. Oleh karena itu, penggunaan Google Classroom ini sesungguhnya mempermudah guru dalam mengelola pembelajaran dan menyampaikan informasi secara tepat dan akurat kepada peserta didik (Hakim, 2016).

Pada penelitian ini bertujuan mendeskripsikan belajar mahasiswa menggunakan Aplikasi Google Classroom dalam matakuliah Matematika Diskrit pada masa pandemic covid-19. Harapannya belajar mahasiswa menggunakan Aplikasi Google Classroom dapat berlangsung dengan baik, dapat diakses dimanapun, serta kapanpun sehingga dapat dimanfaatkan untuk proses belajar mengajar khususnya pada masa pandemic covid-19 seperti sekarang ini.

\section{METODE}

Penelitian ini menggunakan metode penelitian deskriptif kuantitatif (Maolani \& Cahyana, 2016). Pendekatan kuantitatif yang digunakan yaitu berupa angket dan wawancara. Tujuan dari penelitian ini adalah mendeskripsikan belajar mahasiswa menggunakan Aplikasi Google Classroom dalam matakuliah Matematika Diskrit pada masa pandemic covid-19.

Penelitian ini dilaksanakan mulai semester ganjil tahun akademik 2020/2021 pada Mahasiswa semester $\mathrm{V}$ matakuliah Matematika Diskrit sebanyak 34 orang, Program Studi Pendidikan Matematika. FSTT UNDIKMA Mataram. Instrumen yang digunakan dalam penelitian ini adalah berupa angket/kuisioner dengan menggunakan google form. Google Form atau google formulir adalah alat yang berguna untuk membantu merencanakan acara, mengirim survei, memberikan siswa atau orang lain kuis, atau mengumpulkan informasi yang mudah dengan cara yang efisien. Form dapat dihubungkan ke spreadsheet Mulatsih, B. (2020). Wawancara dilakukan pada saat akhir kegiatan belajar mengajar secara daring. Analisis data dilakukan dengan menggunakan excel untuk menghitung jumlah persentase serta nilai rata-rata.

Indikator angket diberikan pada mahasiswa terdiri dari ; 1) Respon siswa mudah dalam mengakses Aplikasi Google Classroom, 2) keefektifan dalam pembelajaran Matematika Diskrit dalam menggunakan Aplikasi Google Classroom, 3) pemahaman terhadap materi dalam pembelajaran dengan menggunakan Aplikasi Google Classroom, (4) mudah pemahaman materi Matematika Diskrit jika menggunakan aplikasi Aplikasi Google Classroom selama masa Pandemi Covid 19. (5) motivasi mahasiswa dalam melakukan belajar online karena menggunakan Aplikasi Google Classroom,(6) kualiatas interaksi guru dan siswa dalam Pembelajaran menggunakan Aplikasi Google Classroom (Trisnawati, 2021).

Sedangkan indikator pertanyaan wawancara terhadap siswa meliputi 1) Keinginan siswa dalam pembelajaran pada saat pandemi. 2) Bagaimana keadaan signal internet selama pembelajaran menggunakan Aplikasi Google Classroom. 3) Permasalan siswa yang dihadapi pada saat pelaksanaan pembelajaran secara daring 4) Solusi dalam menangani permasalahan pembelajaran tersebut. (Trisnawati, 2021)

\section{HASIL DAN PEMBAHASAN}

Penelitian ini dilaksanakan mulai semester ganjil tahun akademik 2020/2021 pada Mahasiswa semester $\mathrm{V}$ matakuliah Matematika Diskrit sebanyak 34 orang. Data hasil penelitian ini diperoleh melalui angket serta hasil wawancara kepada mahasiswa secara daring. Adapun data hasil penelitian ini berdasarkan indikator yang digunakan tersaji pada tabel1 berikut ini: 
Tabel 1. Hasil persentase penerapan Aplikasi

\begin{tabular}{|c|c|c|c|}
\hline No & Indikator & Setuju & $\begin{array}{c}\text { Tidak } \\
\text { Setuju }\end{array}$ \\
\hline 1 & $\begin{array}{lr}\text { Respon siswa mudah } \\
\text { dalam mengakses } \\
\text { Aplikasi } \\
\text { Classroom, }\end{array}$ & $64.71 \%$ & $35.29 \%$ \\
\hline 2 & $\begin{array}{lr}\text { Keefektifan } & \text { dalam } \\
\text { pembelajaran } & \\
\text { Matematika Diskrit } & \text { Dam menggunakan } \\
\text { dalam } & \text { Aplikasi } \\
\text { Classroom } & \\
\end{array}$ & $73.53 \%$ & $26.47 \%$ \\
\hline 3 & $\begin{array}{lr}\begin{array}{l}\text { Pemahaman } \\
\text { materi }\end{array} & \begin{array}{r}\text { derhadap } \\
\text { dalam }\end{array} \\
\text { pembelajaran } & \text { dengan } \\
\text { menggunakan } & \\
\text { Aplikasi } & \text { Google } \\
\text { Classroom } & \end{array}$ & $79.41 \%$ & $20.59 \%$ \\
\hline 4 & $\begin{array}{lr}\text { Mudah } & \text { pemahaman } \\
\text { materi } & \text { Matematika } \\
\text { Diskrit } & \text { jika } \\
\text { menggunakan aplikasi } \\
\text { Aplikasi } & \text { Google } \\
\text { Classroom } & \text { selama } \\
\text { masa Pandemi } & \text { Covid } \\
19 & \end{array}$ & $73.53 \%$ & $26.47 \%$ \\
\hline 5 & $\begin{array}{l}\text { Motivasi mahasiswa } \\
\text { dalam melakukan } \\
\text { belajar online karena } \\
\text { menggunakan } \\
\text { Aplikasi Google } \\
\text { Classroom }\end{array}$ & $82.35 \%$ & $23.53 \%$ \\
\hline 6 & $\begin{array}{l}\text { Kualiatas interaksi } \\
\text { guru dan siswa dalam } \\
\text { Pembelajaran } \\
\text { menggunakan } \\
\text { Aplikasi Google } \\
\text { Classroom }\end{array}$ & $79.41 \%$ & $20.59 \%$ \\
\hline \multicolumn{2}{|c|}{ Rata-rata } & $75.5 \%$ & $25.5 \%$ \\
\hline
\end{tabular}

Berdasarkan tabel 1, dapat kita lihat hasil analisis data persentase penerapan Aplikasi Google Classroom dalam matakuliah Matematika Diskrit pada masa pandemi covid-19. Untuk indikator pertama yaitu Respon siswa mudah dalam mengakses Aplikasi Google Classroom diperoleh sebanyak $64.71 \%$ mahasiswa setuju dan $35.29 \%$ mahasiswa tidak setuju. Sehingga dapat disimpulkan bahwa mahasiswa lebih mudah mengakses Aplikasi Google Classroom.

Kemudian, untuk memperjelas informasi peneliti juga melakukan wawancara kepada mahasiswa dan hasilnya diperoleh bahwa mahasiswa mudah menggunakan dan mengakses Aplikasi Google Classroom karena dapat dilakukan kapan saja, dan dimana saja, baik dengan menggunakan laptop ataupun smartphone mereka masingmasing. Hal ini senada seperti yang disampaikan oleh Utami, R (2019) berdasarkan hasil penelitiannya menyatakan bahwa "Google Classroom mudah digunakan oleh mahasiswa karena mahasiswa bisa lebih cepat mengakses materi, tugas maupun pengumuman penting dari Google Classroom yang bisa diakses lewat $P C$ maupun Smartphone yang dimiliki mahasiswa. Mahasiswa juga lebih mudah untuk belajar karena bisa mengakses Google Classroom dimana saja, sehingga siswa tertarik dan senang untuk belajar matakuliah Psikologi Pembelajaran Matematika. Ketertarikan mahasiswa dalam pembelajaran menyebabkan mahasiswa lebih memahami materi yang disampaikan dosen".

Hanya saja kendala yang di dapat oleh beberapa mahasiswa yaitu kondisi signal yang kurang stabil, karena pada masa pandemic covid-19 ini mahasiswa rata-rata belajar dari rumah masing-masing. Sehingga dengan demikian, ada pula mahasiswa yang berasal dari daerah yang cukup jauh dari jangkauan signal. Sependapat dengan hal tersebut Mulatsih, B. (2020) menyatakan bahwa hasil penelitiannya juga menemukan beberapa kendala dalam mengakses Aplikasi Google Classroom yaitu 1) Tidak semua siswa tinggal di wilayah yang sinyal internetnya mendukung pembelajaran daring; 2) Jaringan internet yang terkadang tidak lancar; 3) Adanya keterbatasan kuota yang dimiliki beberapa siswa.

Indikator kedua: Keefektifan dalam pembelajaran Matematika Diskrit dalam menggunakan Aplikasi Google Classroom diperoleh persentase sebesar $73.53 \%$ mahasiswa yang setuju dan sebesar $26.47 \%$ mahasiswa tidak setuju. Hal ini menunjukkan bahwa dengan Aplikasi Google Classroom efektif digunakan untuk kegiatan belajar. Dengan demikian dapat disimpulkan bahwa pembelajaran Matematika Diskrit efektif 
menggunakan Aplikasi Google Classroom. Hal ini didukung oleh Santosa, F. H., Negara, H. R. P., \& Bahri, S. (2020) berdasarkan hasil penelitiannya bahwa pembelajaran menggunakan Google Classroom terhadap kemampuan penalaran matematis siswa efektif. Google Classroom efektif digunakan oleh dosen untuk menyampaikan materi kepada mahasiswa (Dhia Ghina Ramadhani Putri S, 2017).

Indikator ketiga: Pemahaman terhadap materi dalam pembelajaran dengan menggunakan Aplikasi Google Classroom diperoleh sebesar $79.41 \%$ mahasiswa setuju sedangkan sebesar $20.59 \%$ mahasiswa tidak setuju. Jika dilihat dari angket ada sebanyak 27 orang mahasiswa yang paham akan materi, sedangkan sebanyak 7 orang mahasiswa tidak paham materi. Dengan demikian dapat disimpulkan bahwa dengan menggunakan Aplikasi Google Classroom mahasiswa paham akan materi yang diberikan setelah belajar menggunakan Aplikasi Google Classroom.

Indikator keempat: Mudah pemahaman materi Matematika Diskrit jika menggunakan Aplikasi Google Classroom selama masa Pandemi Covid 19 sebesar $73.53 \%$ mahasiswa menyatakan setuju dan sebesar $26.47 \%$ mahasiswa menyatakan tidak setuju. Sehingga dapat disimpulkan bahwa mahasiswa mudah paham materi dengan belajar menggunakan Aplikasi Google Classroom. Selain itu, tampilan Google Classroom sangat jelas dan mudah dipahami oleh mahasiswa. Google Classroom juga memberikan kemudahan dalam memperoleh pengumuman, materi dan pengumpulan tugas menjadi lebih fleksibel Arifin, S. R., \& Merdekawati, E. G. (2020)

Indikator kelima: Motivasi mahasiswa dalam melakukan belajar online karena menggunakan Aplikasi Google Classroom diperoleh nilai sebesar $82.35 \%$ mahasiswa setuju sedangkan nilai sebesar $23.53 \%$ mahasiswa tidak setuju. Oleh karena itu dapat disimpulkan bahwa mahasiswa termotivasi belajar dengan menggunakan Aplikasi Google Classroom. Dari keenam indikator yang ada, maka indikator kelima ini yang skornya paling besar dari yang lainnya. Setelah diterusi dengan mewawancarai mahasiswa, rata-rata mahasiswa menyatakan bahwa belajar dengan dengan menggunakan Aplikasi Google Classroom sangat mudah oleh karena itu mahasiswa termotivasi dengan baik untuk belajar.

Googlee classroom merupakan aplikasi yang memiliki beberapa keunggulan, antara lain : proses settingannya cepat, menghemat waktu, dapat meningkatkan kerjasama dan komunikasi, penyimpanan data terpusat di Google Classroom, dan dapat berbagi sumber daya dengan cepat (Mulatsih, B. 2020). Dampak positif yang dirasakan oleh mahasiswa yang belajar dengan menggunakan Aplikasi Google Classroom adalah merasa lebih berani dalam berpendapat, lebih mandiri dan bertanggung jawab dalam mengerjakan tugas, mendapat pengetahuan dan pengalaman baru mengenai aplikasi yang digunakan untuk perkuliahan online, mendapat waktu yang cukup longgar untuk mengerjakan tugas yang diberikan dosen, merasa telah menggunakan internet secara optimal (tidak hanya menggunakan internet untuk membuka media sosial), mudah dalam mengakses dan menyimpan bahan perkuliahan (Febrilia, B. R. A., Nissa, I. C., Pujilestari, P., \& Setyawati, D. U. 2020).

Indikator keenam: Kualiatas interaksi guru dan siswa dalam Pembelajaran menggunakan Aplikasi Google Classroom diperoleh sebesar $79.41 \%$ mahasiswa yang menyatakan setuju serta sebesar $20.59 \%$ mahasiswa yang menyatakan tidak setuju. Sehingga dapat disimpulkan bahwa dengan menggunakan Aplikasi Google Classroom mudah terjadinya interaksi antara dosen dan mahasiswa dalam kegiatan belajar. Interaksi yang terjalin dalam belajar dapat dilihat dari beberapa hal yaitu 1) adanya presensi, 2) dosen menyediakan materi, video belajar serta LKM, 3) dosen dapat memantau kegiatan belajar mahasiswa dengan tersedianya fitur chat pada Aplikasi Google Classroom sehingga dosen dapat memberikan kesempatan kepada mahasiswa untuk bertanya dan berdiskusi terkait dengan materi yang diajarkan. 


\section{KESIMPULAN}

Berdasarkan indicator penerapan Aplikasi Google Classroom menunjukan ratarata mahasiswa menjawab setuju sebesar $75.5 \%$ dan tidak setuju sebesar $25.5 \%$. Hasil tersebut menunjukan bahwa penerapan Google Classroom mendapatkan tanggapan yang baik dari mahasiswa, sehingga dapat digunakan untuk pembelajaran pada matakuliah Matematika Diskrit.

\section{SARAN}

Pelaksanaan pembelajaran dengan menggunakan Aplikasi Google classroom dapat terus digunakan oleh dosen dan mahasiswa, karena Aplikasi Google Classroom mudah diakses, efektif, mudah paham materi, termotivasi dalam belajar serta proses belajar dapat interaktif. Selain itu Aplikasi Google Classroom mempermudah guru untuk mengelola kelas, antara lain untuk memberi pengumuman, mengirim tugas, sarana pengumpul tugas dan penyimpan daftar nilai siswa.

\section{DAFTAR PUSTAKA}

Aliya, Humaira. 2021. Kenali Google Classroom, Masa Depan Layanan Pengajaran Berbasis Online. [Online] Tersedia: https://glints.com/id/lowongan/googl e-classroom-adalah/\#.YHxNcvkzbIV [29 Maret 2021]

Arifin, S. R., \& Merdekawati, E. G. (2020) Tanggapan Mahasiswa terhadap Pemanfaatan Google Classroom sebagai Media Pembelajaran Online. JUSTIN (Jurnal Sistem dan Teknologi Informasi), 8(3), 278-281.

Astini, N. K. S. (2020). Pemanfaatan teknologi informasi dalam pembelajaran tingkat sekolah dasar pada masa pandemi covid19. Lampuhyang, 11(2), 13-25.

Dhia Ghina Ramadhani Putri S. (2017). Communication Effectivness Of Online Media Google Classroom In Supporting The Teaching and Learning Process At Civil
Engineering University Of Riau. JOM FISIP, 4(1), 1-15.

Febrilia, B. R. A., Nissa, I. C., Pujilestari, P., \& Setyawati, D. U. (2020). Analisis Keterlibatan dan Respon Mahasiswa dalam Pembelajaran Daring Menggunakan Google Classroom di Masa Pandemi Covid19. FIBONACCI: Jurnal Pendidikan Matematika dan Matematika,6(2), 175-184.

Gusty, S., Nurmiati, N., Muliana, M., Sulaiman, O. K., Ginantra, N. L. W. S. R., Manuhutu, M. A., ... \& Warella, S. Y. (2020). Belajar Mandiri: Pembelajaran Daring di Tengah Pandemi Covid-19. Yayasan Kita Menulis.

Hakim, A. B. (2016). Efektifitas Penggunaan E-Learning Moodle, Google Classroom Dan Edmodo. vol, 2, 1-6.

Juliangkary, E., \& Pujilestari, P. (2021). Hasil Belajar Mahasiswa Terhadap Penggunaan Google Classroom Pada Matakuliah Matematika Diskrit. Jurnal Ilmiah Mandala Education, 7(2).

Maolani A.R. dan Cahyana U. (2016). Metodologi Penelitian Pendidikan.Rajagrafindo Persada: Jakarta

Mulatsih, B. (2020). Penerapan aplikasi Google Classroom, Google Form, dan Quizizz dalam pembelajaran kimia di masa pandemi Covid19. Ideguru: Jurnal Karya Ilmiah Guru, 5(1), 16-26.

Santosa, F. H., Negara, H. R. P., \& Bahri, S. (2020). Efektivitas pembelajaran google classroom terhadap kemampuan penalaran matematis siswa. Jurnal Pemikiran Dan Penelitian Pendidikan Matematika (JP3M), 3(1), 62-70.

Trisnawati, (2021). Penerapan Aplikasi Google Meet Dalam Pembelajaran Matematika Di Kelas XI SMA Negeri 9 Samarinda Pada Masa Pandemi Covid-19. Sistema: Jurnal Pendidikan 02 (01) (2021) 
Utami, R. (2019, February). Analisis Respon Mahasiswa terhadap Penggunaan Google Classroom pada Mata Kuliah Psikologi Pembelajaran Matematika. In Prisma, Prosiding Seminar Nasional Matematika (Vol. 2, pp. 498-502). 